\title{
Morphological, anatomical and biochemical studies on the foliar galls of Alstonia scholaris (Apocynaceae)
}

\author{
SUSY ALBERT ${ }^{1,2}$, AMEE PADHIAR $^{1}$, DHARA GANDHI ${ }^{1}$ and PRIYANKA NITYANAND ${ }^{1}$
}

(received: April 23, 2010; accepted: June 30, 2011)

\begin{abstract}
Morphological, anatomical and biochemical studies on the foliar galls of Alstonia scholaris (Apocynaceae)). Morphological, anatomical and biochemical alterations in foliar galls of Alstonia scholaris R. Br. induced by the insect Pauropsylla tuberculata (Psyllidae) are described and quantified. Galls occur isolated or agglomerated on the abaxial surface of the leaf. The insect along with the egg deposits some physiologic fluid which act as a stimulant for the induction of the gall. This stimulus brings about hypertrophy followed by hyperplasia of cells next to the location of the deposited eggs. The psyllid presents three nymphal instars, from eclosion of the egg to the adult. Hyperplasia in the palisade cells is very distinctly noticed. Hypertrophy followed by hyperplasia takes place and brings about elevation of hypodermal and palisade parenchyma which undergoes repeated anticlinal divisions. Neoformation of phloematic bundles were distinctly noticed close to the site of infection. With an increase in the growth of the gall, chlorophyll content in the gall tissue decreases. A steady increase of sugar content is noticed. The immature galled tissue showed almost two fold increases in the protein content. The mature galled tissue showed a very high increase in the proline content compared to the immature galled tissue indicating a stressed condition of the galled tissue.
\end{abstract}

Key words - hyperplasia, hypertrophy, Pauropsylla tuberculata

RESUMO - (Estudos morfológicos, anatômicos e bioquímicos em galhas foliares de Alstonia scholaris (Apocynaceae)). Alterações morfológicas, anatômicas e bioquímicas nas galhas foliares de Alstonia scholaris, induzidas pelo inseto Pauropsylla tuberculata (Psyllidae), são aqui descritas e quantificadas. As galhas ocorrem isoladas ou aglomeradas na superfície abaxial da folha. O inseto, juntamente com os ovos, deposita fluidos fisiológicos que atuam como um estimulante na indução da galha. Este estímulo gera hipertrofia seguida por hiperplasia das células localizadas próximas ao local de deposição dos ovos. O inseto apresenta três estágios de instares ninfais, a partir da eclosão do ovo até o adulto. A hiperplasia das células do parênquima paliçádico é bem distinta. A hipertrofia seguida pela hiperplasia ocorre e causa uma elevação da hipoderme e do parênquima paliçadico que sofre repetidas divisões anticlinais. A neoformação de feixes floemáticos é distinta próxima ao local da infecção. Com o aumento no crescimento da galha, o conteúdo de clorofila nos tecidos da galha diminui. Ocorre um aumento constante no conteúdo de açúcares. $\mathrm{O}$ tecido da galha madura mostra um aumento grande no conteúdo de prolina quando comparado ao tecido da galha imatura, indicando a condição de estresse do tecido galhado.

Palavras-chave - hiperplasia, hipertrofia, Pauropsylla tuberculata

\section{Introduction}

Anatomical studies on leaf galls induced by Cecidomyiidae (Diptera) indicate profound modifications at cell and tissue levels (Rohfritsch 1992, Kraus et al. 2003). The insect activates a perturbation in growth mechanisms and alters the differentiation processes in the host plant, modifying the plant architecture to its advantage (Raman 2007). Conspicuous palisade parenchyma proliferation and cell hypertrophy were reported in Piptadenia gonoacantha (Mart.) J. F. Macbr. (Fabaceae) (Arduin \& Kraus 1995), whereas in galls induced on Guarea macrophylla subsp.

1. The Maharaja Sayajirao University of Baroda, Faculty of Science, Department of Botany, Sayajigunj, Vadodara Pincode 390002, Gujarat, India.

2._Correspondig author: drsusyalbert@rediffmail.com tuberculata (Vell.) T. D. Penn. (Meliaceae) the spongy parenchyma cells also divide and become round with small intercellular spaces. Gall formation on the leaves of Baccharis concinna G. M. Barroso (Asteraceae) causes alterations in pericyclic fibers, which lose their ordinary secondary walls noticed in healthy leaves (Arduin \& Kraus 2001). The insects are known to extract nutrients from the phloem, xylem or non-conducting plant cell (Meyer 1987). Growth of gall tissues are associated with the changes in the levels of their cellular contents such as carbohydrates, proteins, nucleic acids, phenols, IAA and enzymes (Arya et al. 1975).

Several gall inducing thrips and eriophyid mites in India have been documented along with their host plants. But limited notes on gall inducing psyllids and their host plants are available. The gall inducing species of Hemiptera are distributed into four superfamilies; Aphidoidea, Psylloidea, Coccoidea and Aleyrodoidea 
(Raman 2003). Within the Psyllidae, there are nearly 350 widely distributed gall inducing species occurring mainly on the leaves of dicotyledonous plants (Hodkinson 1984). Psyllid galls usually contain only one nymph per chamber, but some galls have been found to house more than one nymph. Psyllid galls may have either simple or complex structures, and can be found either isolated or aggregated (Hodkinson 1984, Dreger-Jauffret \& Shorthouse 1992, Raman 2003).

Raman (2003) provided valuable information on the different plant galls in India and cecidogenetic behavior of some gall inducing insects and morphogenesis of their galls. However several galls still remain to be discovered in India. The anatomical, biochemical and developmental (ontogenesis) aspects of leaf galls induced by many insects still remain unexplored.

The present work aims to describe the morphoanatomical and biochemical changes taking place during the different developmental stages of foliar galls in Alstonia scholaris R. Br. that were induced by the gallmaker Psyllidae, Pauropsylla tuberculata Crawford. This study emphasizes changes in foliar tissues compared with non-infested ones, so that more is known on the interactions between gallmakers and the host plants. Emphasis of the study is mainly on the alterations that take place in the leaves due to the formation of gall by Pauropsylla tuberculata.

\section{Material and methods}

Morphology of Alstonia scholaris - Alstonia scholaris (Apocynaceae) is a small tree, abundant in Western India. It is around $40 \mathrm{~m}$ tall with greenish white fragrant flowers. It is commonly called as the "Devil tree". The bark is grayish, branchlets are copiously lenticellate. Leaves occur in whorls of 3-10; petioles are 1-3 cm; the leathery leaves are narrowly obovate to very narrowly spathulate, base cuneate, apex usually rounded; lateral veins occur in $25-50$ pairs, at $80-90^{\circ}$ to midvein. The upperside of the leaves are glossy, while the underside is grayish (figures 1,2). The infected plant shows crumpled and disfigured leaves (figure 3 ).

Sampling - Mature galled and ungalled leaves of Alstonia scholaris were collected from infested and uninfested trees growing around Akota located at Vadodara in Gujarat. Samples of healthy and galled leaves by the Psyllidae in different developmental stages were collected at the canopy of five Alstonia scholaris individuals. Randomly 10 mature galled leaves were collected from each individual. The youngest gall developmental stage was determined based on the smallest diameter, observed as a small spot bulged on the leaf blade. The mature ungalled leaves and galls of different developmental stages were taken to the laboratory for morphological and anatomical analyses. Care was also taken to collect the insect during its different developmental stages.

Morphological analysis - Galls were observed morphologically under dissecting microscope in laboratory. Photographies of different developmental stages of leaf galls were taken out in the laboratory as well as in the field. The live insect and its nymphal stages were collected in bottles along with the gall. The insect was identified and confirmed as Pauropsylla tuberculata by Dr. K. Sujata and Dr. Bhumika Naidu from The Maharaja Sayajirao University.

Anatomical analysis - For structural analysis, samples were fixed on the spot in FAA with 70\% ethanol (Johansen 1940), stocked in $70 \%$ ethanol and gradually dehydrated in TBA (tert-butyl alcohol) series and embedded in paraffin (Johansen 1940). Samples were sectioned $(10 \mu \mathrm{m})$ on Leica RM 2035 rotary microtome. For histological studies sections were stained in safranin and fast green (Sass 1951). The presence of starch grains and phenolic substances were located histochemically by potassium-iodide (Johansen 1940, Mace 1963).

Biochemical analysis - For biochemical analysis, fresh samples from the same study area were collected. For convenience the collected samples of leaves were categorized into: (A) Ungalled leaves of uninfested plants; (B) Ungalled leaves of infested plants; (C) Young gall; (D) Mature gall.

Standard procedures were followed for the analysis of proteins (Bradford 1976), chlorophyll content (Arnon 1949), sugars (Yemn \& Willis 1954) and proline (Bates et al. 1973).

\section{Results}

Ungalled leaves of Alstonia scholaris are dorsiventral (figures 4, 5). The upper epidermal cells are tubular, compactly arranged and covered with a moderately thick cuticle (figure 4). The lower epidermal cells are papillate, with an outer papillose wall and inner flat wall parallel to the leaf surface (figure 5). Lower epidermis is covered by a thick cuticle which is echinulate at the region of the papilla. Stomata confined to the lower epidermis are sunken in depressions formed by the incurving of the epidermal cells (figure 6).

Developmental stages of Pauropsylla tuberculata - The adult of Pauropsylla tuberculata lays eggs on the abaxial surface of the developing leaves. Eggs are laid singly or grouped at more than one place. The eggs appear white, oblong, narrow and acute at one end (figures 7 , 8). It is presumed that the insect along with the egg deposits some physiologic fluid which acts as a stimulant for the initiation of the gall. Lysis of the cells occurs 

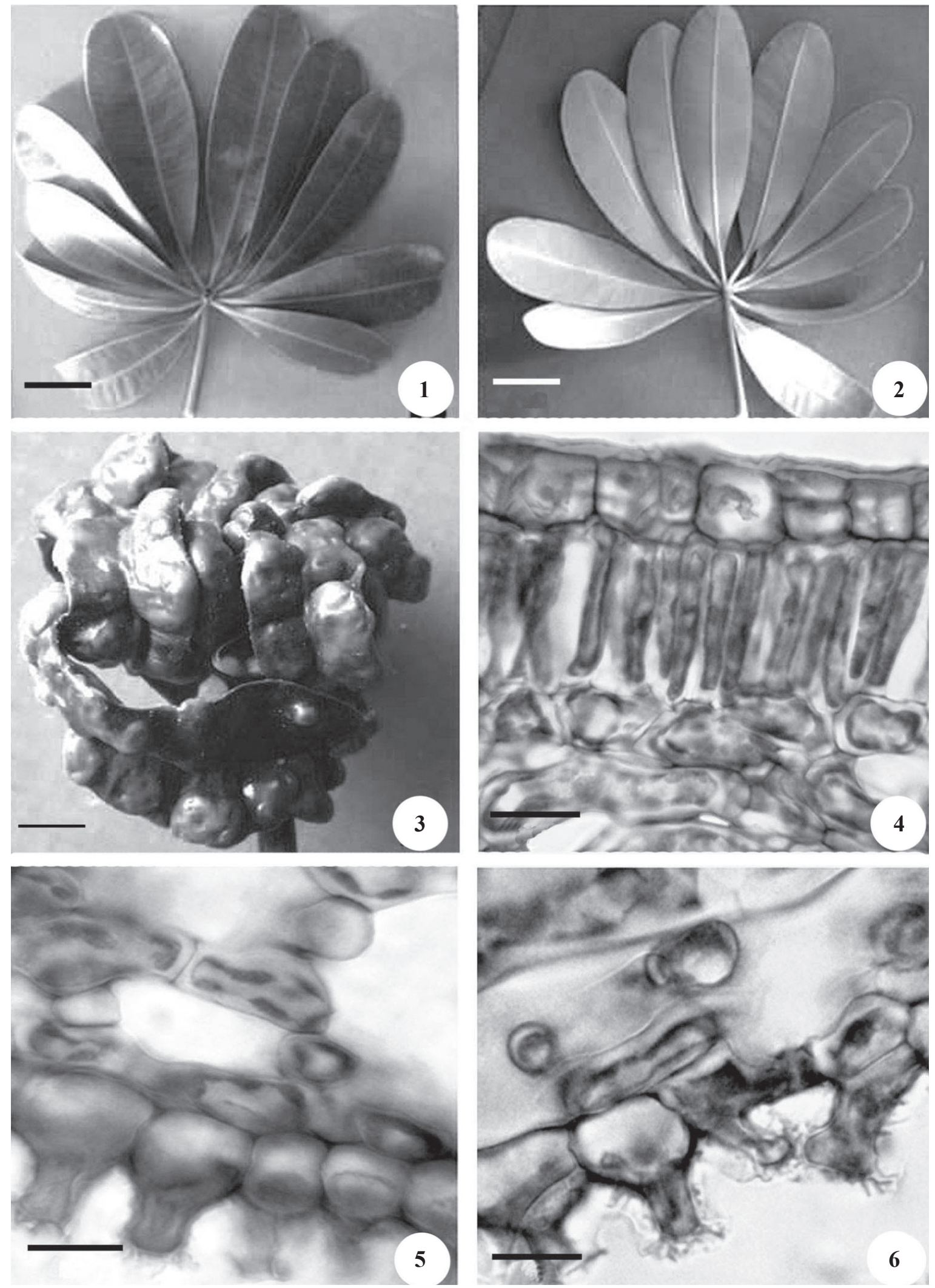

Figures 1-6. Leaves of Alstonia scholaris. 1. Whorl leaf (adaxial view). 2. Whorl leaf (abaxial view). 3. Deformed crinkled leaf at terminal portion of the branch due to gall development. 4. Adaxial epidermis with thick cuticle followed by a single layer of palisade cells. 5. Abaxial papillated epidermal cells. 6. Stomata at lower epidermis protected by papillated abaxial epidermal cells. $\mathrm{Bar}=5 \mathrm{~cm}(1,2,3) ; 5 \mu \mathrm{m}(4,5,6)$. 
leading to the formation of a depression (figure 9). This process stimulates hypertrophic response resulting in cell division and subsequent formation of the gall. The nymph (the first instar) undergoes moulting to reach the adult stage (imago).

The nymph is yellow and all the instars are developed inside the zoocecidia. At the time of emergence the exit hole is made either on the dorsal or ventral side of the leaf. Characteristic white waxy secretion of the nymph occurs in abundance surrounding it (figure 10). Moulted exuviae of second and third instars are often found on the leaf surface (figure 11).

Pauropsylla is a hemimetabolous insect and so does not have larve and pupa stage as holometabolous insects. Its life cycle starts with egg $\rightarrow$ nymph $\rightarrow$ adult stage. It is believed that as they have no pupa, their wings develop in small buds on the outside of their body which can be distinctly observed as small white buds on the body of the nymph. This is probably the second instar (figure 12).

The third instar looks quite similar to the adult form. Body is ovate with distinct thorax and abdomen. Setae are present all over the body. The lower/dorsal side of the body is clothed with long setae and the setae on the ventral side are small and spine like. Eyes are not bulging out and the antennae are long, tapering and straight (figure 13). The mature insect is also yellow in colour, winged and with bulging eyes (figure 14). These insects after nuptial flight appear to probably ovipost eggs on the galled leaves (figure 15).

Morphological alterations in the leaf - Galls are formed on both abaxial and adaxial surfaces of the leaves. But they are abundant on the abaxial surface (figures 16, 17). Initiation of the gall formation results from the oviposition on leaves by Pauropsylla tuberculata. The first visible change is a slight decolorisation on the areas where the eggs are deposited. Chemical stimulus brings about degeneration of surrounding cells forming a small cavity within which the egg lies. Gradually the decolorized area increases in size and forms a small outgrowth on an adaxial side where the gall appears enlarged and placed in a depression or a small circular spindle shaped pit. At initial stage the gall grows towards the abaxial side of the leaf but later on its growth is towards the adaxial side. A little bulge appears on the adaxial side of the leaf which further develops into a dome shaped structure.

The galls are mainly formed on the lateral veins (figures 18, 19). The nymph at initial stage is enclosed within the gall tissue. A cover cone rapidly grows over the insects from the tissue surrounding and enclosing it completely. The maximum number of galls was found lateral to the second order veins. These are atriate galls with cavities within. The cavity is lined by closely packed mass of chlorophyll lacking cells. Cells surrounding the cavity are rich in starch grains forming a nutritive tissue. This is surrounded by a very thick mass of parenchyma with some conductive tissues. When the leaves are heavily galled the lamina has been completely reduced to a single agglomerate mass of cells. Young and mature leaves are affected. With an increase of galls in number all the leaves appear crumbled and completely deformed (figure 20). The leaf galls occur scattered and isolated (figure 24) or in agglomerated clusters (figures 21-23) resulting in the crinkling of the leaves.

With further development on the surface of the gall a depression/halo is formed (figure 21). The chamber formed is open to the abaxial side by means of a small opening/ostiole. Apparently with the further growth of the gall the ostiole becomes indistinct and a well defined cavity is formed. The mature epiphyllous pouch galls are unilocular with a single chamber or multilocular with 3-4 chambers. The mature gall is monothalamus subcylindrical, concolorous with the host leaf, except at the apex which is yellowish. The wall is thick and succulent. The chamber is subcuneate with the sharp edge pointing distal end. The opening is apical, subcircular without any appendage. The galls are persistent remaining on the leaf long after the escape of the Cecidozoa. The galls appear multilocular because the adjacent galls coalesce. The number of galls varies from 25 to numerous on a leaf. Depending upon the maturity of the galls the diameter of the gall chamber ranges from $0.1 \mathrm{~cm}$ to $1 \mathrm{~cm}$. The mature gall externally does not differ much from the previous stages except in size. The whole gall appears fleshy. The nymph at its third or fourth instar emerges from a small circular opening formed in the centre of the gall (figures 22, 23).

The senescent stage is characterized by the presence of small orifices on the gall surface. After the emergence of the insects the cells close to the chamber and exit canals form a protective layer which appears as a yellowish brown rim (figure 24).

Anatomical alterations in the infected leaf - In the initial stage the leaf lamina was barely thickened, but hypertrophied in the site oviposition. The palisade and spongy parenchyma did not suffer much alteration at the beginning (figure 25). The abaxial epidermis (figure 26) followed by spongy mesophyll starts rapidly dividing. The proliferation occurs vigorously around the deposited 

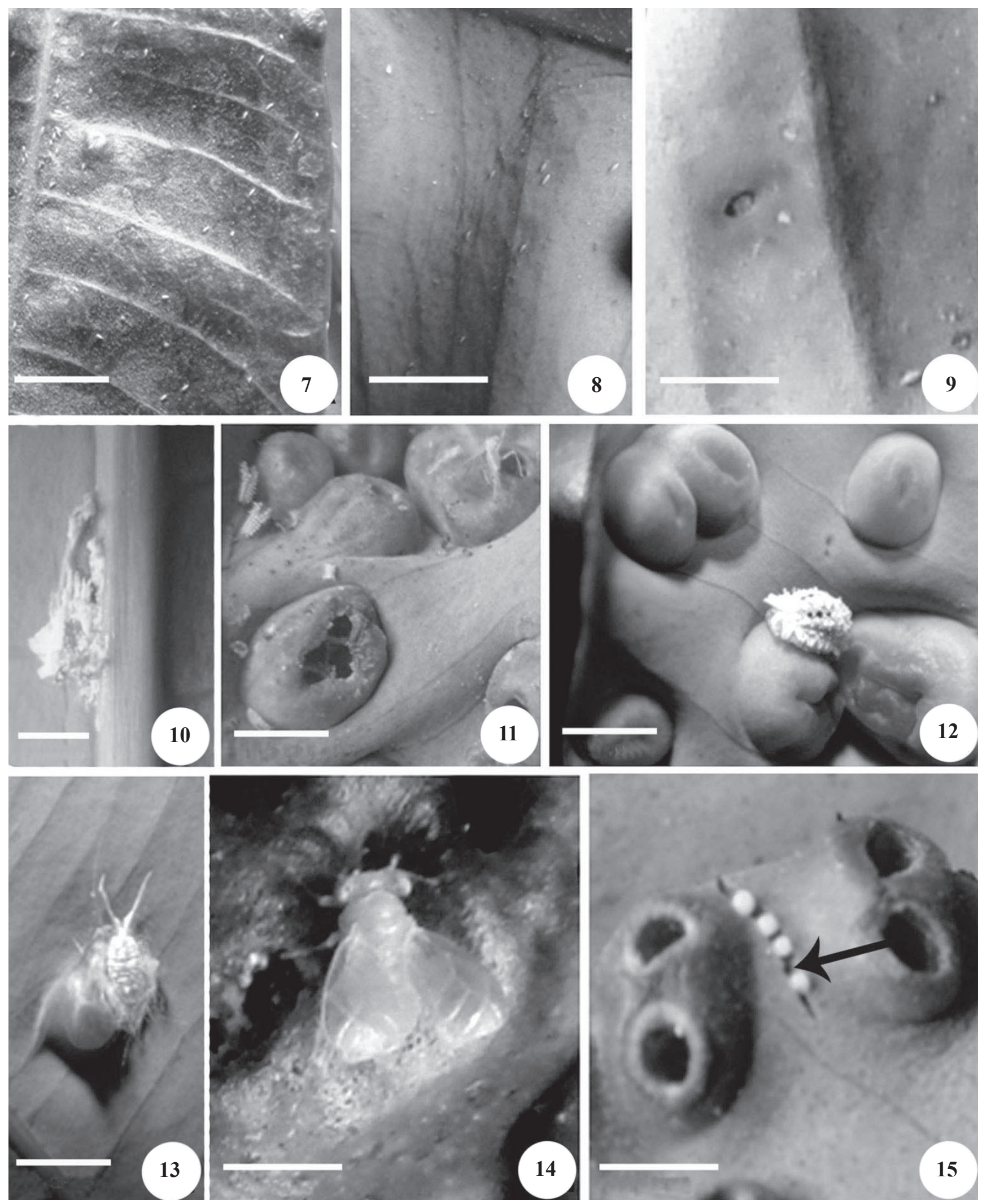

Figures 7-15. Leaves of Alstonia scholaris. 7. Eggs on abaxial surface of leaf. 8. Eggs on adaxial surface of leaf. 9. Water sogged and depressed pit with egg. 10. White waxy secretion surrounding nymph. 11. Moulted exuviae of fourth and fifth instars on leaf surface. 12. Fourth instar of nymph. 13. Fifth instar of nymph. 14. Mature insect. 15. Eggs deposited linearly and cracked epidermis (arrow). Bar $=0.5 \mathrm{~cm}(7,11,12,13) ; 25 \mathrm{~mm}(8,9,14.15) ; 2 \mathrm{~mm}(10)$. 

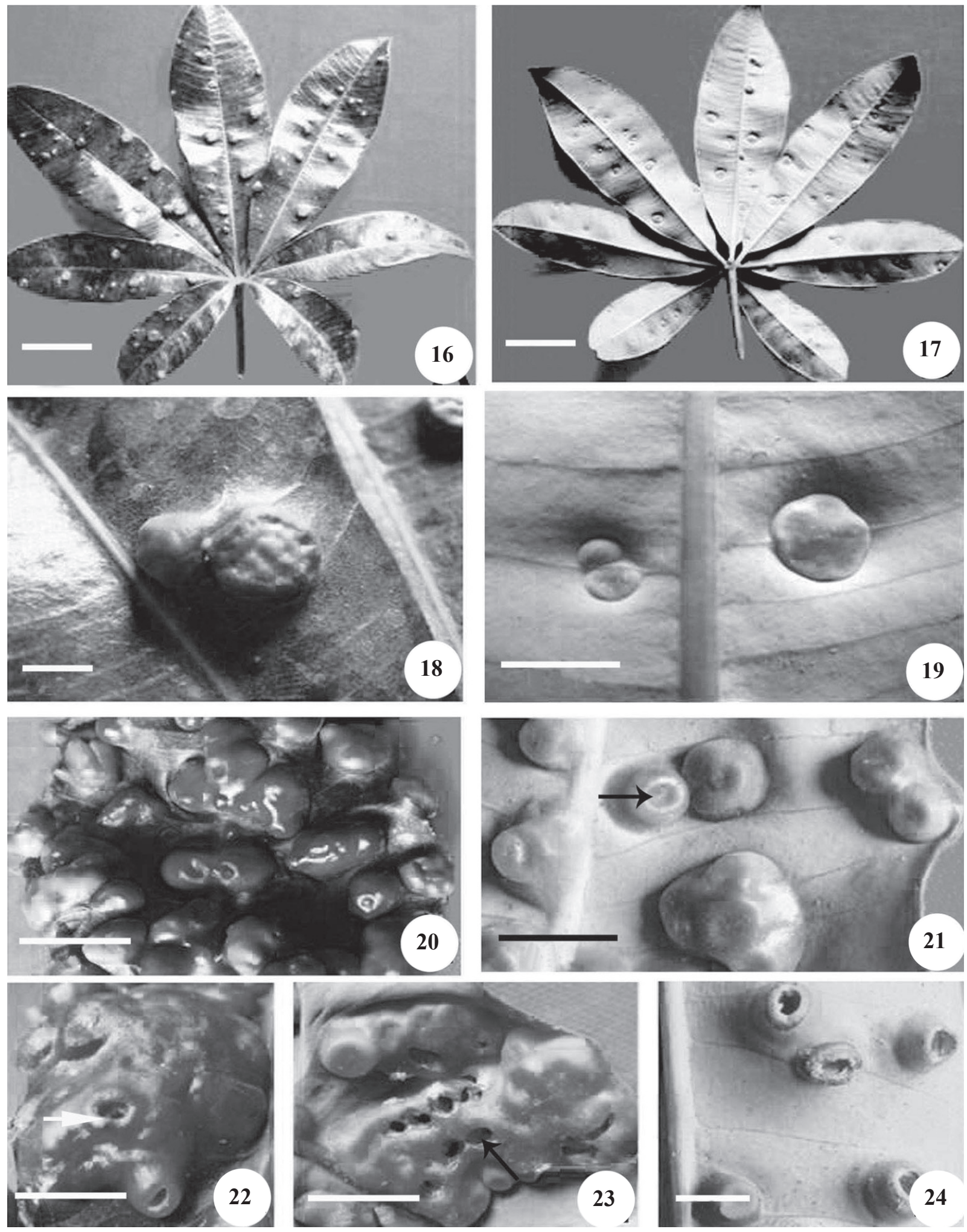

Figures 16-24. Leaves of Alstonia scholaris. 16. Adaxial surface of the leaf showing initial stages of galls. 17. Abaxial surface of leaf showing galls. 18. Gall initiated on lateral vein (adaxial surface). 19. Galls initiated on lateral veins (abaxial surface). 20. Leaf crumpled and deformed due to increased number of galls (adaxial view). 21. Galls on abaxial surface showing depression in the centre (arrow). 22. Galls in cluster (abaxial view). 23. Agglomerated/fused galls with nymphal chambers showing ostiole (arrow). 24. Yellowish brown periderm formed at the rim of the opening. Bar $=5 \mathrm{~cm}(16,17) ; 0.5 \mathrm{~cm}(18$, $19,20,21,22,23,24)$. 
egg. This results in formation of a specific zone of hypertrophic cells. This hypertrophy of the epidermis and hyperplasia of cells immediately surrounding the nymph produces an upward evagination on the abaxial side of the leaf enclosing the egg. Periclinal divisions of the cells give rise to neoformed tissue (figure 26). These cells later on get hypertrophied occupying a large area. The cells appear highly vacuolated and elongated (figure 27).

At the site of infection the lower epidermis gets invaginated forming a sunken pit (figure 28). The papillated lower epidermis is continous throughout the pit. Cells of the epidermis and the spongy cells proliferate and become hypertrophied (figure 29). Cambium like radially flattened cells arise below the lower epidermis (figure 30), which divide and give rise to compactly arranged parenchyma cells. The papillate lower epidermis in the process of division becomes flattened. The papillate outer walls become flat like the inner walls (figures 29, 31). As a result of rapid hyperplasia and hypertrophy, a cover zone is formed around the pit deepening the pit further (figures 32, 33). The leaf at this site loses the differentiation of spongy and palisade parrenchymas.

The region of the midrib comprise of epidermis, collenchyma located next to abaxial surface and adaxial surface, cortical parenchyma and vascular system consisting of abundant xylem and phloem. Abaxial cortical parenchyma were interspersed with large secretory cells (figures 34, 35), which were apparently distinct because of its large size compared to the adjacent cells.

When the gall initiation is on the adaxial surface, a trail of salivary sheath was observed leading to xylem (figure 36) of the collateral vascular bundle located in spongy parenchyma below the palisade cells which becomes highly elongated. Periclinally dividing cells are found close to xylem (figure 37, asterisk).

Vascular tissues show an elongated wedge formation (figure 37). The number of compactly arranged parenchyma cells have increased in the mesophyll region and a noticeable reduction in intercellular space takes place. The mesophyll region appears homogenous. Figure 38 shows the lysis of epidermal cells inducing gall formation.

The chemical stimulus initiates division in the surrounding epidermal cells (figures 39, 40). The epidermal layers increase and the palisade cells become shorter (figure 41). The palisade cells gradually are replaced by thin walled compactly arranged parenchyma. The hypertrophied cells appear large, round (figure 42) and compactly arranged. At the site where eggs are deposited lysis of cells continues below the epidermal layer leading to the formation of a crack in the epidermis (figures 42, 43).

Physiological secretion from the mother insect the introducing of saliva causes the lysis of cells of the epidermis and mesophyll. The space increases and deepens the crack indicating the pathway of the stimulus (figure 42, arrow). Adjacent cells show presence of dark contents (figure 43). This stimulus brings about hypertrophy of cells adjacent to the location. Beneath the chamber new developing vascular tissues are observed (figure 43, arrow).

Hyperplasia in the palisade cells are very distinctly noticed (figures 44-46). Hypertrophy followed by hyperplasia takes place and brings about elevation of hypodermal and palisade parenchyma which undergoes division by repeated anticlinal division (figure 47). The cells increase in size and gradually lose the chloroplasts. Within the proliferating tissue procambial cells and differentiating xylem and phloem elements were observed (figures 48-50). A large lysigenous cavity is formed adjacent to the phloem elements (figure 51) consequently forming the nymphal chamber. The nymphal chamber further increases in size (figures 52 , 53) with the development of nymph.

Adjacent to the enlarging chamber large parenchymatous cells show conspicuously large starch grains (figures 54, 55). The growth of the gall is due to more vacuolation, enlargement of cells and increase in the size. With further lysis of the cells the chamber increases in size (figures 56-58) and the nymphal stages are complete. The cells undergoing lysis appeared compressed and deformed (figure 59). The gall is by now open on the adaxial side of the cavity or more often on abaxial side. The whole gall appears to be fleshy. Lining the chamber a periderm like layer is formed (figure 60). The cells formed by the phellogen are large and feebly lignified (figure 61) forming a protective covering to the exposed chamber.

Changes in the cellular contents of the gall during different stages of gall development - The changes in the cellular content of galls during the different stages of its development are represented graphically (figure $62)$.

Chlorophyll - Tissues of ungalled leaves of uninfested and infested tree showed a slight variation. The galled tissues showed a decrease in the chlorophyll content with the increase in the growth of the gall becoming very low level in the mature gall. 

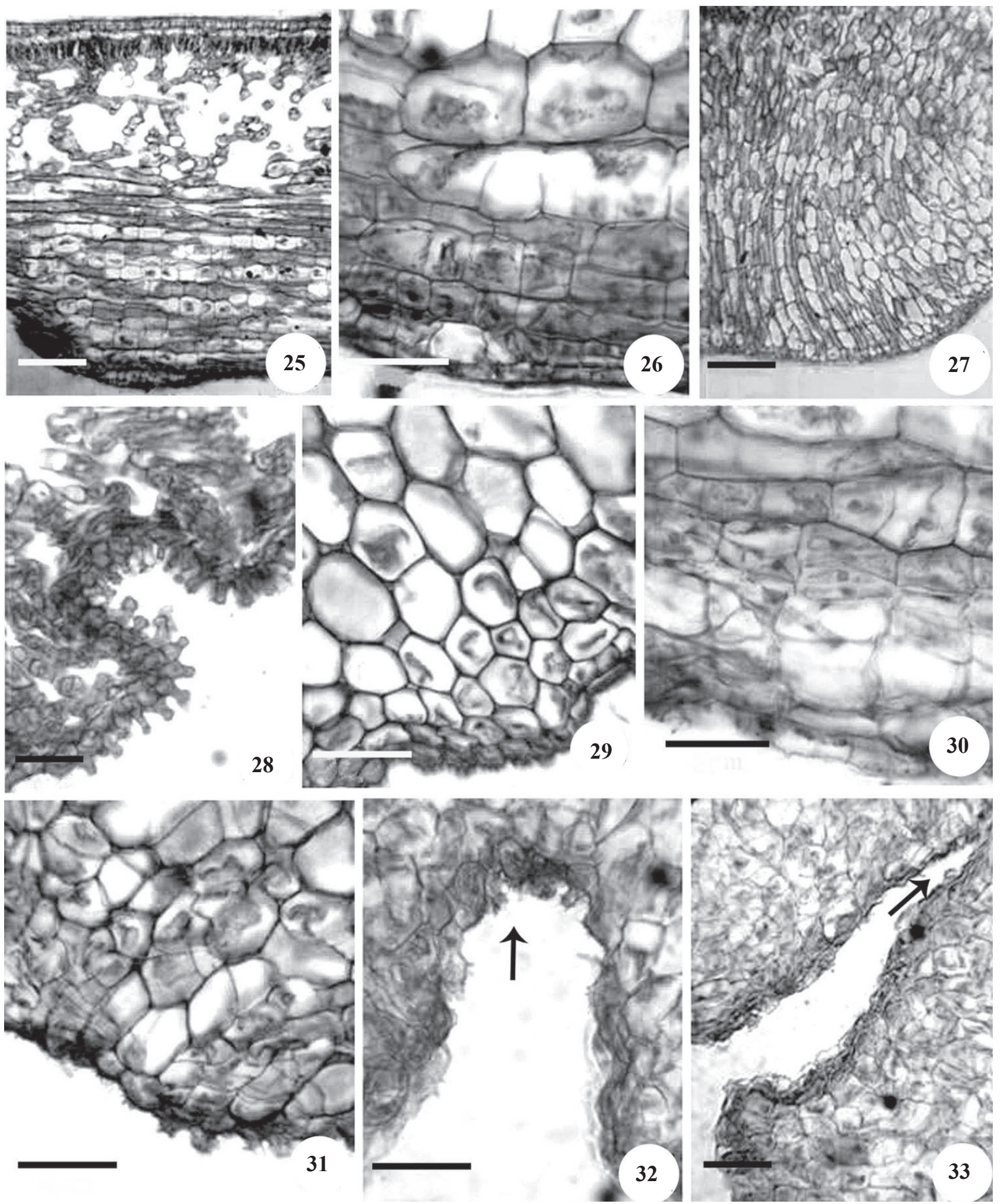

Figures 25-33. Anatomical aspects of Alstonia scholaris leaves. 25. Initial stage of gall formation. Leaf is dorsiventral with hyperplasia at the abaxial region. 26. Dividing abaxial epidermal cell. 27. Hypertrophied cells on abaxial side of the leaf. 28. Abaxial epidermis invagination forming a sunken pit at the site of infection. Note the papillate cells continuous in the sunken region. 29. Papillate cells lose its identity and appear barrel shaped. 30. Radially flattened cambium cells above abaxial epidermis. 31. Abaxial papillated epidermal cells flattened. 32. Enlarged pit on abaxial surface of the leaf (arrow). 33. Hyperplasia and hypertrophy around the pit, deepening pit (arrow). $\mathrm{Bar}=20 \mu \mathrm{m}(25,27,33) ; 5 \mu \mathrm{m}(26,28,29,30,31,32)$. 

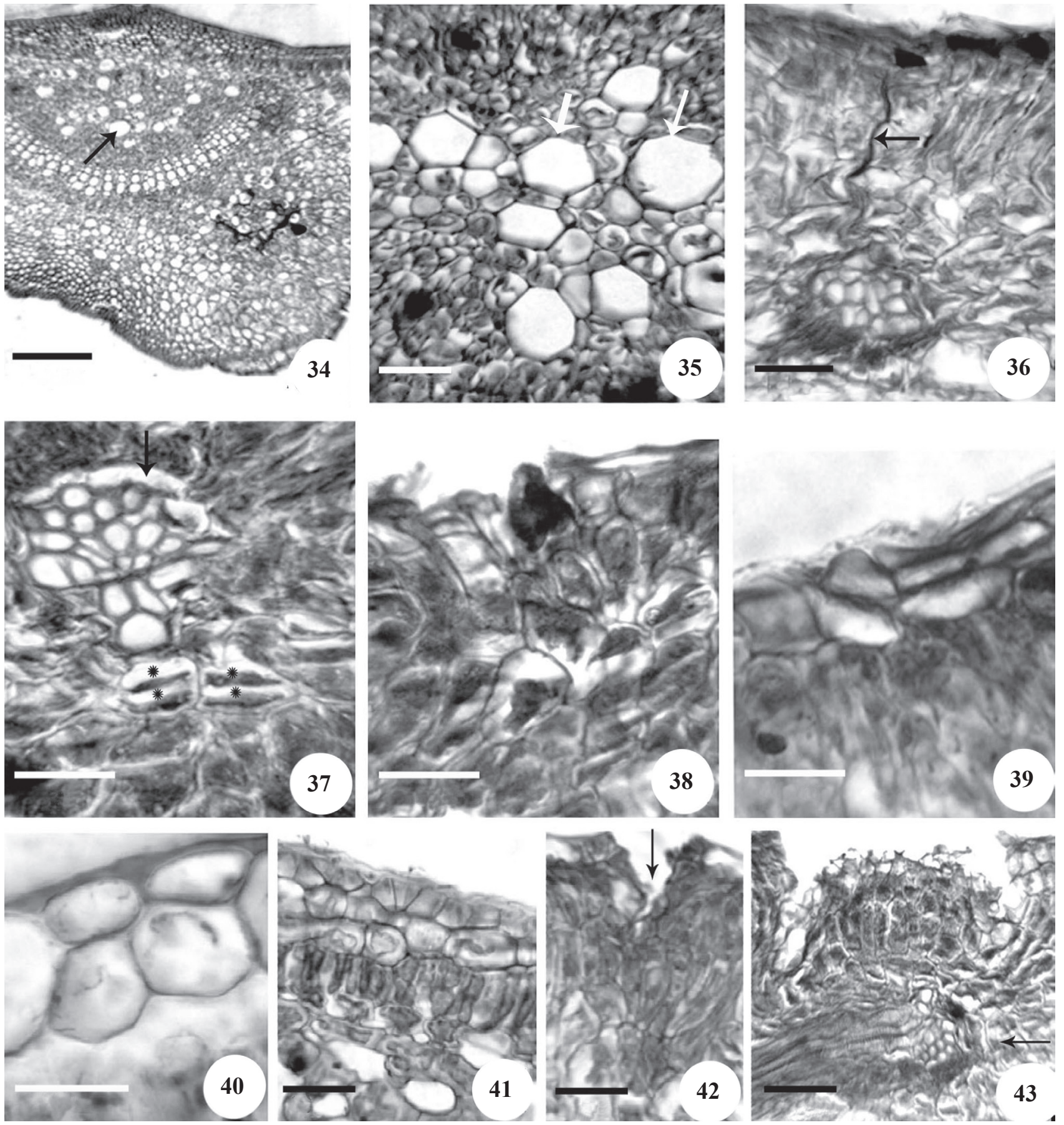

Figures 34-43. Anatomical aspects of Alstonia scholaris leaves. 34. Abaxial parenchyma in midrib showing secretory cells (arrow). 35. Magnified view of midrib region showing secretory cells (arrows). 36. Trail of salivary sheath (arrow). 37. Periclinally dividing cells formed closed to xylem (asterisk); the arrow shows the wedge shaped vascular bundle. 38. Lysis of adaxial epidermal cells. 39-40. Division initiated in epidermal cells. 41. Hypertrophied adaxial epidermal cells and palisade cells. 42. Cracked adaxial epidermal layers; the space increases and deepens the crack (arrow). 43. Newly developing vascular tissues (arrow). Neighbouring cells of cracked epidermis with dark contents. Bar $=50 \mu \mathrm{m}(34) ; 10 \mu \mathrm{m}(35,36,41,42,43) ; 5 \mu \mathrm{m}(37,38,39,40)$.

Total sugars - The level of sugars in the ungalled leaves of uninfested and infested trees show no variation. A steady increase of sugar content is noticed in the galled leaves and the burst gall registered the highest level.
Total protein - Protein content in normal leaf of uninfested plant and infested tree was more or less equal. The unburst galled tissue showed almost two fold increase in the protein content. The protein content 

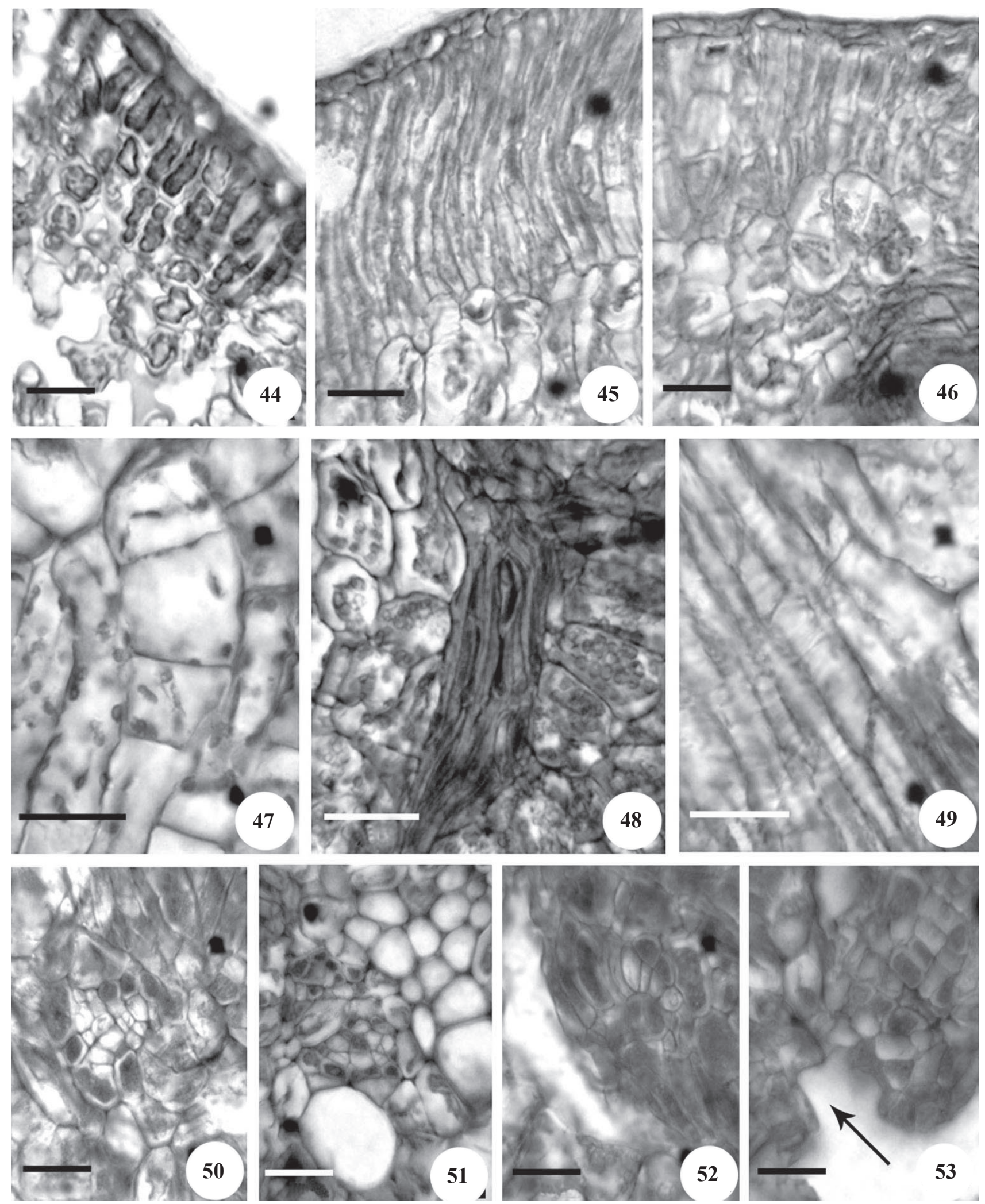

Figures 44-53. Anatomical aspects of Alstonia scholaris leaves. 44. Hyperplasia in the palisade layer. 45-46. Palisade cells elongated, spongy cells replaced by large round parenchyma cells. 47. Dividing palisade cells. 48. Newly developed procambial strands surrounded by parenchyma cells with starch grains. 49. Vessel elements in differentiation. 50. Newly formed phloem strands. 51. Lysigenous cavity formed adjacent to phloem elements. 52-53. Cell lysis in phloem region increasing the size of nymphal chamber (arrow). Bar $=10 \mu \mathrm{m}(44,45,46,50,51,52,53) ; 5 \mu \mathrm{m}(47,48,49)$. 

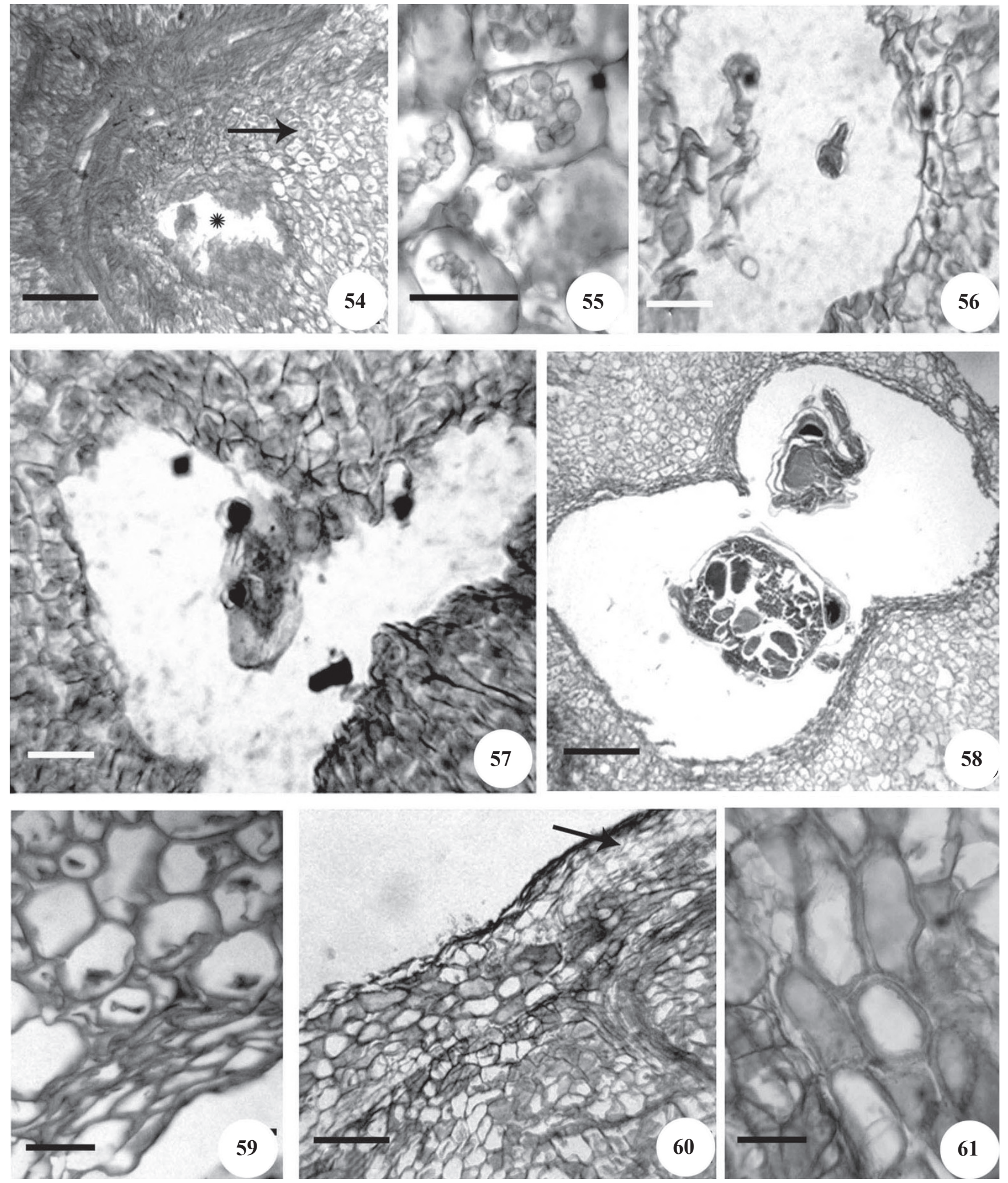

Figures 54-61. Anatomical aspects of Alstonia scholaris leaves. 54. Nymphal chamber formed by disintegration of cells (asterisk). Arrow indicates cells with starch grains. 55. Parenchyma cells with large number of starch grains. 56-58. Nymphal chamber showing different instars. 59. Cells lining the chamber becoming deformed and compressed. 60. Periderm (arrow) formed in the tissue lining the nymphal chamber. 61 . Feebly lignified cells close to the periderm. Bar $=50 \mu \mathrm{m}(54,58,60)$; $5 \mu \mathrm{m}(55) ; 20 \mu \mathrm{m}(56,57) ; 10 \mu \mathrm{m}(59,61)$. 


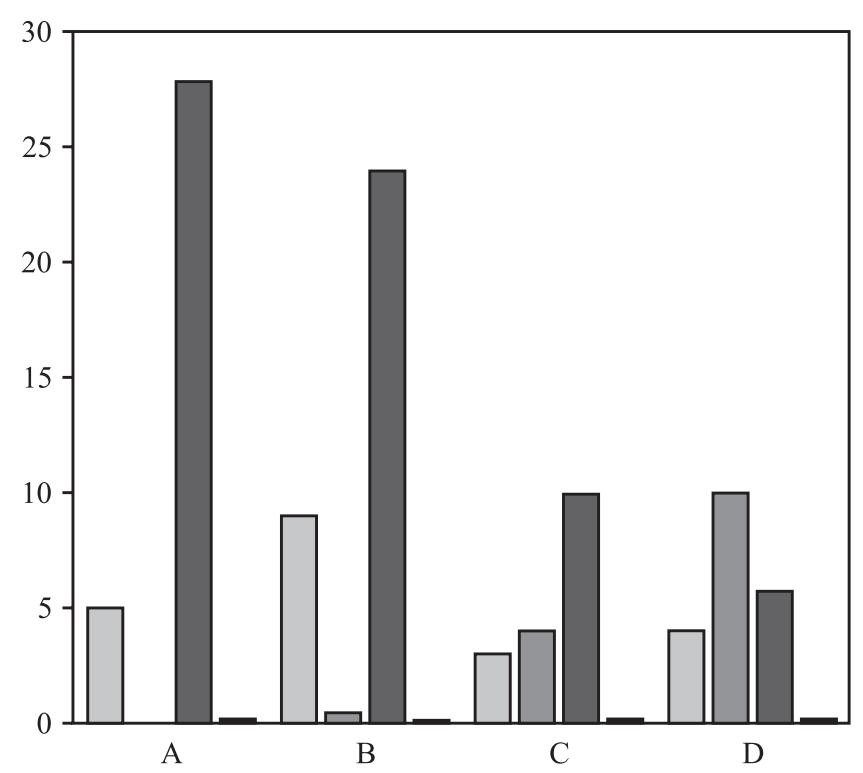

Figure 62. Cellular contents during the different stages of gall development. $(\mathrm{A}=$ ungalled leaves of uninfested plant; $\mathrm{B}=$ ungalled leaves of infested plants; $\mathrm{C}=$ young gall; $\mathrm{D}=$ mature gall; $\square=$ protein; $\square=$ proline; $\square$ chlorophyll II; $\square=$ sugars).

showed an initial increase and registered the highest level during the young galled stage of their development and declined thereafter in the mature burst galled tissue where in the nymphal stage had already exited out from the chamber.

Proline - A normal leaf from an uninfected tree showed absolutely no trace of proline. A normal leaf of the infested branch of an infested tree showed a very low concentration of proline. The galled tissue showed a very high increase in the proline content and in the mature gall the content was very high almost double fold than the young gall indicating stressed condition of the galled tissue.

\section{Discussion}

With about 2000 different galls (thus almost the same number of inducing-insect species exists), the Indian subcontinent displays a rich variety in gall flora (Raman 2007). Among the insects various hemipteran are known to be capable of inducing galls (Meyer 1987, Rohfritsch 1992, Wool et al. 1999, Raman 2003). In the Psyllidae, there are close to 350 species of gall inducers which attack primarily leaves of dicotyledons (Hodkinson 1984). Pauropsylla tuberculata (Psyllidae), a gall inducer on leaves of Alstonia scholaris, is an example of this group of galling insects.
Galls on Alstonia scholaris caused by Pauropsylla tuberculata is a covering pouch gall in which the plant tissue grows around and above enclosing the cecidozoa that lies initially exposed on the surface of the organ. Many authors have reported different morphological types of galls on the same plant caused by different insects (Arduin et al. 1991, Gonçalves Alvim \& Fernandes 2001, Scareli-Santos \& Varanda 2003). In Alstonia scholaris only one type of gall was observed.

According to Rohfritsch's (1992) young plant tissues are regarded to present responses against inducing insects when compared to already differentiated tissues. Galls in A. scholaris occur on both young and mature leaf tissues indicating that tissues in such species react against the inducing insects regardless the leaf age. Similar results have been found in other species (Arduin \& Kraus 2001, Scareli-Santos \& Varanda 2003, ScareliSantos et al. 2008).

Eggs of $P$. tuberculata deposited on the leaves triggers the induction of gall. The nymphal stages feed on the leaf, where the eggs were deposited and stimulate gall development by translocating a chemical stimulus on the adaxial and abaxial side of the A. scholaris leaves. Mc Calla et al. (1962), working on the leaf galls of willow induced by sawflies, observed that the initial stimulus for the initiation of gall formation comes from the fluid formed in accessory glands of female which is injected into the plant by female at the time of egg laying. By depositing multiple eggs at the same host location, multichambered galls develop and such a development is considered as an evolved trait among gall inducing insects (Stone et al. 2002). The saliva causes the lysis of the upper epidermis and mesophyll or the infolding of the papillate lower epidermis. This stimulus brings about hypertrophy of cells next to the location of the deposited eggs. Hypertrophy is followed by intense hyperplasia which takes place and brings about elevation of palisade parenchyma which undergoes division by anticlinal division. The psyllid present three nymphal instars, from eclosion of the egg to the mature insect, displaying mechanisms that protect them from loss of humidity (Gullan \& Martin 2003, Raman 2003). Free feeding psyllids are more active during periods of higher humidity while others produce wax as a strategy to avoid water loss (Arduin et al. 2005). Pseudophacopteron (Psyllid) galls on Aspidosperma australe Muell. Arg. another member of Apocynaceae maintain communication with their immediate environment through an ostiole and also have its chamber lined with wax (Christiano 2002). In contrast psyllids galls on A. scholaris are entirely closed and 
chambers are not lined by any waxy secretion. However the nymphs appear to produce waxy deposit around it once it comes out of the chamber (see figure 10). Within Psyllidae galls, with few exceptions, nutritive tissue formations were not observed (Meyer 1987, Rohfritsch 1992). Hemipteran insects exhibits a sucking feeding habit. These insects introduce stylets into the tissue and, they take some time exploring the tissue and injecting viscose substances forming a salivary sheath (Arduin et al. 2005). This salivary sheath is considered to facilitate the penetration of the insect proboscis or prevent the plant unleashing hypersensitivity reactions to combat the damage inflicted upon it (Fernandes 1990, Milles 1999). Raman (2003) considered the penetration to be intercellular with the dissolution of middle lamella of the adjacent cells, though Spiller et al. (1985) and Tjallingh \& Hogen Esch (1993) revealed that this always was not the case, because the stylet can penetrate between the wall and the plasmatic membrane and may even display an intracellular path. In Alstonia scholaris the salivary sheath was observed extended into the palisade parenchyma and reaching xylem element of the galls. The same type of observation was noted by Arduin et al. (2005) on Baccharis dracunculifolia DC. (DC.). In hemipteran galls, the vascular system may be altered. Notably gall vascular bundles were predominately phloematic in Alstonia scholaris as observed in galls induced by Schizomyia macrocapillata Maia on Bauhinia brevipes Vogel (Sá et al. 2009) and by the gall midge Izeniola obesula Dorchin on Suaeda monoica Forssk. (Dorchin et al. 2002). In the galls induced by Geoica wertheimae Brown \& Blackman (Pemphigidae; Forminae) on Pistacia palestina Boiss. (Anacardiaceae), seven layers of cells were identified as phloematic which facilitated the access of the inducers to alimentary resources (Wool et al. 1999). An increase in phloem tissues was also observed in Baccharopelma dracunculifoliae DC. gall. Most of them showed a lack of xylem cells (Arduin et al. 2005).

The non differentiation of these lignified cells was also observed in the ambrosia galls induced by an unidentified species of Cecidomyidae on leaves of Baccharis concinna L. (Arduin \& Kraus 2001) and may indicate that the energy otherwise used to differentiate lignified cells is deviated to other gall requirements. Phloematic bundles indicates the establishment of a photosynthetates drain to the gall tissues (Rohfritsch 1992, Sá et al. 2009). Induction followed by enlargement of the nymphal chamber is seen close to phloem cells in P. tuberculata galls on Alstonia scholaris. Predominant phloematic bundles were reported for other galls (Kraus et al. 2003, Arduin et al. 2005) and it plays an important role in nutrient supply of the growing gall at the expense of the other plant tissue (Vandevyvere \& De Bruyn 1998).

Galls are considered a significance drain on leaf resources (Fay et al. 1993, Nyman \& Julkunen-Tiitto 2001). Accumulation of food material such as starch is seen in cells around the cavity. These cells may be functioning as the nutritive tissues. Accumulation of food materials in cells around the nymphal chamber is commonly observed in the foliar galls (Arduin et al. 2005).

Shrinkage and dying up of cells lining the opening in the mature gall has been observed. The size of the ostiole increases facilitating the escape of the insect nymph. The nymph moves through this cleaved passage towards the exit, moults and escapes as an adult winged insect. At gall senescence, around the insect chamber and the exit channel a healing tissue is formed.

Biochemical results in the present study showed variations in the content due to gall formation. Chlorophyll content of gall tissues showed a decrease as growth progressed. This loss of chlorophyll is responsible for the decolourisation of the area of the leaf where egg was laid in Ficus leaves (Moghe 1980). The low chlorophyll content in galled tissues was due to the loss of palisade tissues, disappearance of chloroplast and modifications of spongy mesophyll.

An increase of proline content in the galled leaves of $A$. scholaris occurs compared to the ungalled leaves. Induction of proline in galled tissues indicates that this has been produced due to the stress. Proline is produced as a defence mechanism to protect from invaders (biotic stress) or stress factors (abiotic stress) and are believed to be an adaptive response to the altered conditions. Increase in proline content was observed in galled leaves of Populus (El-Akkad 2004). Proline accumulation is known to be a response to stress condition in plants (Gibon et al. 2000).

The higher protein concentration observed in the galled tissue corroborates the observations of Mehalingam (1999) and Scareli-Santos \& Varanda (2003). It is also in line with Arora \& Patni (2001) and El-Akkad (2004). The formation of gall requires mechanical and chemical stimuli. The fluid which probably contains enzymes and other cecidogenic substances released/injected into the plant by the insect at the time of egg laying triggers gall induction. The action of the stimulus leads to the formation of new tissues, which cover the nymph in order to isolate and to eliminate the invader, the gall forming insects. The gall tissue accumulates starch which 
is not present in the ungalled tissue. The stimulus of gall forming insects redirect growth and differentiation of cells which act as a sink of nutritive substances from the host plants by normal flow of resources and/ or by the active mobilization of neighboring parts of the gall (Hartley 1998).

Synthesis of diverse plant proteins are believed to be of importance in defence is also known (Reinbothe et al. 1994). Defensive proteins that block the action of proteolytic enzymes from herbivores are found in legumes, tomatoes and other plants. These proteins, known as proteinase inhibitors, rapidly seem to accumulate throughout plants that are being fed upon by insects and even accumulate in undamaged areas of plants that are far from the initial feeding site (Ananthakrishnan 2001). So it can be concluded that when plants are attacked by insects they generate signals and one of these signals is the initiator of expression of certain polypeptides that may be useful in providing the basis for new crop protection strategies.

The present study has also shown that the galls of $A$. scholaris are not an uncontrolled tumor growth. Their ontogeny follows a well defined sequence, and produces an equally well defined morphoanatomical structure. These alterations reveal the plasticity of plant tissues which may be controlled by insects. According to Taft \& Bissing (1988), presence of the inducer leads to a rupture of the cellular process of the host, and also results in an active redirection of the existing ontogenetic patterns, to the benefit of the inducer. Schonrogge et al. (2000) detected similar proteins in seeds and in gall tissue suggesting that gall formation might involve the ectopic expressions of genes of other structures of the host plant.

In addition to the explanation that gall inducing insects inhabit a highly specialized habitat, viz., the gall, for nutrition, another opinion is that a gall is an 'enemy free' space protecting the inducing insects from predators and parasitoids (Price et al. 1987). Evidence shows that galls inducing insects are susceptible to heavier levels of relatives (Hawkins et al. 1997). A strong selection pressure for achieving a greater level of 'protection' (e.g. greater level of hardness and thickness of gall walls) prevails on any gall inducing taxon (Stone \& Schonrogge 2003) to reduce the vulnerability of their offsprings to parasitoids and predators.

This study on the gall induced by $P$. tuberculata on A. scholaris complements what, is currently known regarding gall biology and contributes to the knowledge about the plasticity of plant tissues stimulated by biotic factors. However it comforts with concept put forward by Arduin et al. (2005), i.e. pathological tissues reveal a potential not manifested in healthy plant tissue.

Acknowledgments - The authors wish to thank the Head, Department of Botany, Prof. Arun Arya, for providing the facilities to conduct the work; thanks to Dr. Suresh Kumar, Department of Zoology, M.S.University of Baroda, for guidance during preparation of the manuscript.

\section{References}

ANANTHAKRISHNAN, T.N. 2001. Phytochemical defence profiles in insect-plant interactions. In Insects and plant defence dynamics (T.N. Ananthakrishnan, ed.). Science Publishers, Enfield, p.1-21.

ARDUIN, M. \& KRAUS, J.E. 1995. Anatomia e ontogenia de galhas foliares de Piptadenia gonoacantha (Fabales, Mimosaceae). Boletim de Botânica da Universidade de São Paulo 14:109-130.

ARDUIN, M. \& KRAUS, J.E. 2001. Anatomia de galhas de ambrosia em folhas de Baccharis concinna e Baccharis dracunculifolia (Asteraceae). Revista Brasileira de Botânica 24:63-72.

ARDUIN, M., KRAUS, J.E. \& VENTURELLI, M. 1991. Estudo morfológico de galha achatada em folha de Struthanthus vulgaris Mart. (Loranthaceae). Revista Brasileira de Botânica 24:63-72.

ARDUIN, M., FERNANDES, G.W. \& KRAUS, J.E. 2005. Morphogenesis of gall induced by Baccharopelma dracunculifoliae (Hemiptera: Psyllidae) on Baccharis dracunculifolia (Asteraceae) leaves. Brazilian Journal of Biology 65:559-571.

ARNON, D.J. 1949. Copper enzymes in isolated chloroplasts. Plant Physiology 24:1-25.

ARORA, D.K. \& PATNI, V. 2001. Localization of metabolites and enzymes in insect induced rachis gall and normal tissues of Prosopis cineraria (Linn.) Druce. Journal of Phytological Research 14:179-181.

ARYA, H.C., VYAS, G.S. \& TANDON, P. 1975. The problem of tumor formation in plants. In Form, structure and function in plants: Prof. B.M. Johri commemoration volume (H.Y. Mohan Ram, J.J. Shah \& C.K. Shah, eds.). Sarita Publishers, India, p.270-279.

BATES, L-S., WALDREN, R.P. \& TEARE, I.D. 1973. Rapid determination of free proline for water stress studies. Plant and Soil 39:205-208.

BRADFORD, M.M. 1976. A rapid and sensitive method for the qualification of microgram quantities of protein utilizing the principle of protein dye bending. Analytical Biochemistry 72:248-250.

CHRISTIANO, J.C.S. 2002. Respostas cecidogênicas no modelo Aspidosperma australis (Apocynaceae) Pseudophacopteron sp. (Homoptera: Phacopteronidae). Dissertação de mestrado, Universidade de São Paulo, São Paulo. 
DORCHIN, N., FREIDBERG, A. \& ALONI, R. 2002. Morphogenesis of stem gall tissues induced by larvae of two cecidomyiid species (Diptera: Cecidomyiidae) on Suaeda monoica (Chenopodiaceae). Canadian Journal of Botany 80:1141-1155.

DREGER-JAUFFRET, F. \& SHORTHOUSE, J.D. 1992. Diversity of gallinducing insects and their galls. In Biology of insect-induced galls (J.D. Shorthouse \& O. Rohfritsch, eds.). Oxford University Press, Oxford, p.8-33.

EL-AKKAD, S.S. 2004. Biochemical changes induced in Populus nigra leaves by galling aphids Pemphigous populi. International Journal of Agricultural and Biology 6:659-664.

FAY, P.A., HARTNEET, D.C. \& KNAPP, A.K. 1993. Increased photosynthesis and water potentials in Silphium integrifolium galled by cynipid wasps. Oecologia 93:114-120.

FERNANDES, G.W. 1990. Hypersensitivity: a neglected plant resistance mechanism against insect herbivores. Environmental Entomology 19:1173-1182.

GIBON, Y., SULPICE, R. \& LARHER, F. 2000. Proline accumulation in canola leaf discs subjected to osmotic stress is related to the loss of chlorophylls and to the decrease of mitochondrial activity. Physiologia Plantarum 110:469-76.

GONÇALVES-ALVIM, S.J. \& FERNANDES, G.W. 2001. Biodiversity of galling insects: historical, community and habitat effects in the neotropleical savannas. Biodiversity and Conservation 10:79-98.

GULLAN, P.J. \& MARTIN, J.H., 2003. Sternorrhyncha (jumping plant-lice, whiteflies, aphids and scale insects). In Encyclopedia of insects. (V. Resh \& R. Cardé, eds.). Academic Press, Amsterdam p.1079-1089.

HARTLEY, S.E. 1998. The chemical composition of plant galls: are level of nutrients and secondary compounds controlled by the gall- former? Oecologia 113:492-501.

HAWKINS, B.A., CORNELL, H.V. \& HOCHBERG, M.E. 1997. Predators, parasitoids, and pathogens as mortality agents in phytophagous insect populations. Ecology 78:2145-2152.

HODKINSON, I.D. 1984. The biology and ecology of the gall-forming Psylloidea (Homoptera). In Biology of gall insects. (T.N. Ananthakrishnan, ed.). Arnold, London, p.59-77.

JOHANSEN, D.A. 1940. Plant microtechnique. McGrawHill Book Co, New York.

KRAUS, J.E., ISAIAS, R.M.S., VECCHI, C.\&FERNANDES, G.W. 2003. Structure of insect galls on two sympatric subspecies of Chrysothamnus nauseosus (Pall. ex Pursh) Britton (Asteraceae). Boletim de Botânica da Universidade de São Paulo 21:251-263.

MACE, M.E. 1963. Histochemical localization of phenols in healthy and diseased banana roots. Physiologia Plantarum 16:915-925.
MC CALLA, D.R., GENTHE, M.K. \& HOVANTIZ, W. 1962. Chemical nature of an insect gall growth-factor. Plant Physiology 37:98-103.

MEHALINGAM, P. 1999. Histochemical, biochemical and morphogenetic studies on plant gall. Ph.D. Thesis, University of Kamaraj, Madurai.

MEYER, J. 1987. Plant galls and gall inducers. Gerbruder Borntraeger, Berlin.

MILLES, P.W. 1999. Aphid saliva. Biological Review 74: 41-85.

MOGHE, M. 1980. Studies on the insect gall of Ficus racemosa Linn. Ph.D. Thesis, The Maharaja Sayajirao University, Vadodara.

NYMAN, R. \& JULKUNEN-TIITTO, R. 2001. Manipulation of the phenolic chemistry of willows by gall-inducing sawflies. Proceedings of the National Academy of Sciences 97:13184-13187.

PRICE, P.W., FERNANDES, G.W. \& WARING, G.L. 1987. Adaptive nature of insect galls. Environmental Entomology 16:15-24.

RAMAN, A. 2003. Cecidogenetic behavior of some gallinducing thrips, pyllides, coccids, and gall midges, and morphogenesis of their galls. Oriental Insects 37: 359-413.

RAMAN, A. 2007. Insect-induced plant galls of India: unresolved questions. Current Science 92:748-757.

REINBOTHE, S., MOLLENBAUER, R. \& REINBOTHE, C. 1994. JIPs and RIPs: the regulations of plant gene expression by jasmonates in response to environmental cues and pathogens. Plant Cell 6:1197-1209.

ROHFRITSCH, O. 1992. Patterns in gall development. In Biology of insect induced galls (J.D. Shorthouse \& O. Rohfritsch, eds.). Oxford University Press, New York, p.60-86.

SÁ, C.E.M., SILVEIRA, F.A.O., SANTOS, J.C., ISAIAS, R.H.S. \& FERNANDES, G.W. 2009. Anatomical and developmental aspects ofleafgalls induced by Schizomyia macrocapillata Maia (Diptera: Cecidomyiidae) on Bauhinia brevipes Vogel (Fabaceae). Revista Brasileira de Botânica 32:319-327.

SASS, J.E. 1951. Botanical microtechnique. $2^{\text {nd }}$ ed. The Iowa State College, Iowa.

SCARELI-SANTOS, C. \& VARANDA, E.M. 2003. Morphological and histochemical study of leaf galls of Tabebuia ochracea (Cham.) Standl. (Bignoniaceae). Phytomorphology 53:207-217.

SCARELI-SANTOS, C., TEIXEIRA, S.P. \& VARANDA, E.M. 2008. Anatomy of foliar galls of Pouteria torta (Sapotaceae) induced by Voungmyia sp. (Diptera, Cecidomycidae). Phytomorphology 58:139-144.

SCHONROGGE, K., WALKER, P. \& CRAWLEY, M.J. 2000. Parasitoid and inquilines attack in the gall of four alien, cynipid gall wasps: host switches and the effect on parasitoid sex ratios. Ecological Entomology 25: 208-219. 
SPILLER, N.J., KIMMINS, F.M. \& LLEWELLYN, M. 1985. Fine structure of aphid stylet pathways and its use in host plant resistance studies. Entomologia Experimentalis et Applicata 38:293-295.

STONE, G.N. \& SCHÖNROGGE, K. 2003. The adaptive significance of insect gall morphology. Trends in Ecology and Evolution 18:512-521.

STONE, G.N., SCHÖNROGG, E.K., ATKINSON, R.J., BELLIDO, D. \& PUJADE-VILLAR, J. 2002. The population biology of oak gall wasps (Hymenoptera: Cynipidae). Annual Review of Entomology 47:633668.

TAFT, J.B. \& BISSING, D.R. 1988. Developmental anatomy of the horned oak gall induced by Callirhytis cornigera on Quercus palustris (pin oak). American Journal of Botany 75:26-36.
TJALLINGH, W.F. \& HOGEN-ESCH, T. 1993. Fine structure of aphid stylet routes in plant tissues in correlation with EPG signals. Physiological Entomology 18: 317-328.

VANDEVYVERE, I. \& DE BRUYN, L. 1998. Morphological and histochemical analysis of galls of Lipara lucens (Diptera, Chloropidae) on Phragmites australis (Poaceae). Canadian Journal of Botany 76: 1374-1384.

WOOL, D., ALONI, R., BEM-ZVI, O. \& WOLLBERG, M. 1999. A galling aphid furnishes its home with a built-in pipeline to the host food supply. Entomologia Experimentalis et Applicata 91:183-186.

YEMN, E.W. \& WILLIS, A.J. 1954. The estimation of carbohydrates in plant extracts by anthrone. Biochemistry Journal 57:508-514. 